\title{
Lactose intolerance diarrhea in a Quarter-Horse Foal
}

\author{
Diarreia por intolerância à lactose em potro Quarto de Milha
}

\author{
Ana Luisa Holanda de Albuquerque*, Thaís Gomes Rocha, Alexandre Secorun Borges, Simone Biagio Chiacchio, \\ Rogerio Martins Amorim, Jose Paes Oliveira-Filho \\ Universidade Estadual de São Paulo (UNESP), Faculdade de Medicina Veterinária e Zootecnia (FMVZ), Botucatu, SP, Brazil
}

\begin{abstract}
Among diarrhea etiologies in horses, lactose intolerance is a less common or undiagnosed condition. Primary (congenital) lactase deficiency has never been diagnosed in foals, and lactose intolerance secondary to bowel injury has never been described in Brazil. Former bacterial or viral infections that cause severe lesions in the intestinal brush border, the area responsible to produce lactase, will be followed by diarrhea due to a lack of enzyme activity. The present report describes the case of secondary lactase deficiency in a 3-month-old foal with chronic watery diarrhea. The foal had been treated with several antibiotics and dewormed without clinical improvement. Complementary exams made were complete blood count (CBC), white blood cell (WBC) count, fibrinogen levels, serum biochemistry (serum proteins, renal and hepatic functions), blood gas analysis, parasite egg count, abdominal ultrasonography, rectal swab culture for three consecutive days and transtracheal wash. Therapeutic diagnosis was performed through administration of $8 \mathrm{mg} / \mathrm{kg}$ of lactase (PO), every 4 hours, and stool normalization was observed in about eight hours after starting treatment. Lactose intolerance is an important differential diagnosis of diarrhea in young foals.
\end{abstract}

Keywords: Alimentary diarrhea. Lactase deficiency. Horse.

\section{Resumo}

Dentre as etiologias de diarreia em potros, intolerância à lactose é a menos comum ou menos diagnosticada. Diarreia por intolerância à lactose primária (congênita) nunca foi diagnosticada em potros, e intolerância à lactose secundária à lesão intestinal ainda não foi descrita no Brasil. Infecções primárias que causam lesões graves na borda em escova de intestino delgado levam à diarreia por haver menos produção enzimática de lactase. 0 presente relato descreve o caso de diarreia líquida crônica por deficiência de lactase em um potro de 3 meses de idade. 0 potro foi tratado com antimicrobianos e vermifugado, não havendo melhora clínica. Exames complementares realizados foram hemograma, bioquímica sérica (função renal, hepática e proteínas), hemogasometria, coproparasitológico (OPG), ultrassonografia abdominal, cultivo microbiológico de swab retal por três dias consecutivos e lavado transtraqueal. $O$ diagnóstico terapêutico foi realizado com a 
administração de lactase ( $8 \mathrm{mg} / \mathrm{kg}$ ) via oral, a cada quatro horas. Houve normalização das fezes em oito horas após a primeira administração, não sendo realizado nenhum outro tratamento concomitante. Intolerância à lactose é um diagnóstico diferencial importante para casos de diarreia em potros lactentes.

Palavras-chave: Diarreia alimentar. Deficiência de lactase. Cavalo.

\section{Introduction}

Diarrhea is a relevant cause of mortality and morbidity in foals (Magdesian, 2005). It is a clinical manifestation that results from several non-infectious conditions and infectious agents that can range from "foal heat diarrhea" without additional clinical signs to a severe clinical condition that might include the development of sepsis, metabolic acidosis, and hypovolemic shock (McGovern, 2014). One of the causes of diarrhea in foals is lactose intolerance, in most cases (if not all) secondary to infectious pathogens that injure the small intestine, specially Rotavirus and Clostridium difficile (C. difficile) (Magdesian, 2005). Severe enteritis with impairment of the function of the brush border epithelium, where the lactase enzyme is produced, will implicate in inadequate lactose hydrolyzation, and consequently diarrhea (Lomer et al., 2008). This paper describes a case of a three-month-old foal with chronic diarrhea, therapeutically diagnosed as secondary lactose intolerance.

\section{Case report}

A three-month-old Quarter horse foal was presented to the Large Animal Internal Medicine Hospital of the São Paulo State University (UNESP), School of Veterinary Medicine and Animal Science, Botucatu, with persistent watery yellow diarrhea for about 10 days. The animal had already been treated with amikacin $(25 \mathrm{mg} / \mathrm{kg}$, intravenously, every 24 hours) and ceftiofur (5 mg/kg, intravenously, every 24 hours) at the property without clinical improvement. In the physical exam, the animal was dull, mucous membranes were slightly pale, capillary refill time 3-4 s, rectal temperature $37.8{ }^{\circ} \mathrm{C}$, heart rate 96 beats per minute, respiratory rate 32 breaths per minute, and auscultation revealed that all intestinal quadrants were hypermotile and with fluid content.

Complete blood count (CBC), white blood cell (WBC) count, fibrinogen levels, serum biochemistry (serum proteins, renal and hepatic functions), blood gas analysis, parasite egg count, abdominal ultrasonography, rectal swab for three consecutive days and trans-tracheal wash were performed. The foal received supportive treatment with lactated Ringer's fluid and bicarbonate reposition, antibiotic therapy with rifampicin $(10 \mathrm{mg} / \mathrm{kg})$ and azithromycin $(10 \mathrm{mg} / \mathrm{kg})$ P.O. daily, due to the possibility of Rhodococcus equi (R. equi) infection.

\section{Results}

The patient presented clinical improvement, probably because of supportive thera-py, but the diarrhea persisted. The foal's CBC did not present remarkable alterations, and WBC findings were leukocytosis $(24,800$ cells $/ \mu \mathrm{L})$ with neutro-philia ( $92 \%$ of WBC). The foal was also azotemic (BUN: $291 \mathrm{mg} / \mathrm{dL}$ and creatinine: $8.3 \mathrm{mg} / \mathrm{dL}$ ) and presented metabolic acidosis (blood gas pH: 7.23 (ref: 7.36 - 7.46), HCO3 (act): $9.2 \mathrm{mmol} / \mathrm{L}$ (ref: 22 - 29) and BE (ecf): - 17.8 (ref: -4 to 4). Abnormalities detected by ultrasonography examination were small intestine wall thickening $(0.55 \mathrm{~cm})$, and the presence of few comet tails and irregular pleural surface in thoracic ventral areas, bilaterally, although no abscesses were found.

Rectal swab culture isolated Escherichia coli, Enterobacter cloacae and Proteus spp. resistant to all antimicrobials tested, except for norfloxacin. Despite of restrictions of fluoroquinolones use in foals, treatment with norfloxacin $(5 \mathrm{mg} / \mathrm{kg})$ I.V. once a day was instituted, along with bismuth subsalicylate $(3 \mathrm{~mL} / \mathrm{kg})$, and the foal presented stool consistency improvement. At the end of a tenday treatment course, the diarrhea became more frequent and watery (Figure 1). Thus, treatment with $8 \mathrm{mg} / \mathrm{kg}$ of lactase P.O. every four hours was 
attempted. The diarrhea ceased about eight hours after the first lactase administration (Figure 2). Sequentially, the medication was adjusted to every 12 hours maintaining well-formed fecal balls. As the foal did not present relapse of diarrhea, it was discharged with lactase prescription until weaning.

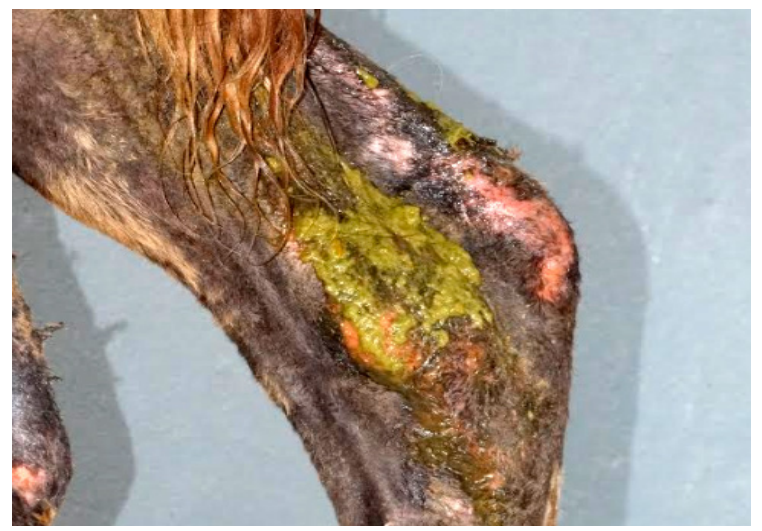

Figure 1 - Faeces aspect and skin injury caused by diarrhea in a 3-month-old foal.

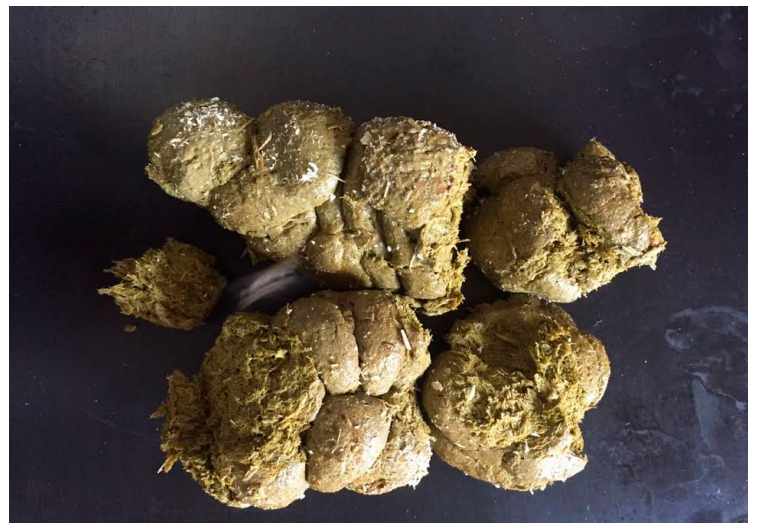

Figure 2 - Faeces aspect after lactase treatment in a 3-monthold foal presented with chronic watery diarrhea.

\section{Discussion}

Diarrhea consists in a more frequent defecation with watery content (Constable et al., 2017). It is a clinical manifestation resulting from several non-infectious conditions and infectious agents (McGovern, 2014). Among non-infectious etiologies of diarrhea, there is "foal heat" diarrhea, usually associated with the mare's first estrus after parturition, which still has a debatable explanation, but is more likely a result of gastrointestinal microbiota establishment (McGovern, 2014). Furthermore, asphyxia gut injury and necrotizing enterocolitis are non-infectious aggressive enteritis, secondary to hypotension and decrease of local perfusion in neonates (Magdesian, 2005). Gastric ulcers might also cause diarrhea but are rather secondary than primary to enteritis (Magdesian, 2005). Nutricional causes of diarrhea include lactose intolerance, although it is generally associated with primary infectious agents, particularly Rotavirus and C. difficile (Lester, 2003). However, any condition that causes significant injury to small intestine brush border may lead to secondary deficiency in lactase production.

Rotavirus is the most frequent pathogen found in foals with diarrhea (Frederick et al., 2009; Slovis et al., 2014). The virus is highly contagious, commonly causing outbreaks (Oliver-Espinosa, 2018). The Rotavirus preferentially infects duodenum and jejunum enterocytes villi and ileum-sparing crypts, followed by malabsorptive diarrhea and a toxin mediated secretory component (Desselberger, 2014). Although Rotavirus is the most important viral etiology of diarrhea in foals, there's also been reports of diarrhea caused by adenovirus (Palmer, 1985) and coronavirus (Davis et al, 2000; Guy et al, 2000).

Clostridium difficile is a Gram-positive anaerobic bacteria. It is one of the most important causative agents of diarrhea in horses (Mallicote et al, 2012), even though it is also isolated from healthy animals (Gustafsson, 2004). The bacteria is only considered pathogenic if capable of producing toxins (Mallicote et al, 2012). Its toxins, $A(\operatorname{tcd} A)$ and $B(\operatorname{tcd} B)$, increase the mucous surface permeability and cause inflammation, leading to fluid exudation, mucous membrane injury and diarrhea (Diab et al., 2013).

Other important bacteria that cause enteritis are C. perfringens, Salmonella typhimurium, Aeromonas hidrofila, Steptococcus durans (Magdesian, 2005), Bacteroides fragilis usually in mixed infections (Myers et al., 1987), $R$. equi (Reuss et al., 2009) and, rarely, E. coli, being most important as agent 
of sepsis in foals (Magdesian, 2005). Despite of isolation of E. coli, Enterobacter cloacae and Proteus spp. in the case described above, it is doubtful that those were the primary agents because those were all enteric bacteria, and it was not possible to perform typification to determine pathogenicity. Positive culture does not confirm the etiology of the diarrhea since several bacteria can be found in feces of healthy animals (Oliver-Espinosa, 2018). Consequently, identification of the etiological agent is not always achievable (Mallicote et al., 2012), and the primary cause of enteritis in the foal here reported remained unknown. Other relevant cause, but discarded in this particular case, is diarrhea caused by parasitic infection, with high prevalence of diarrhea by Strongyloides westeri infection in foals (McGovern, 2014) and less commonly, by Crysptosporidium parvum (Cole et al., 1998).

Lactose intolerance is a clinical syndrome developed after ingestion of lactose, a primary carbohydrate found exclusively in mammalian milk. Interestingly, in comparison with bovine milk, equine milk contains less fat, protein, inorganic salts but more lactose (Uniacke-Lowe, 2010), it is not known if this may predispose lactose intolerance in foals. This clinical syndrome consists in abdominal pain, diarrhea, nausea and flatulency (Oldruitenborgh-Oosterbaan, 2008), although only diarrhea and apathy were reported in the case described. Foals usually became lactose intolerant secondary to enteritis, because the lactase enzyme is produced by the brush border epithelium of the villous enterocyte (Oliver-Espinosa, 2017), where lactose is hydrolyzed by the enzyme into galactose and glucose (Lomer et al., 2008).

There are already 18 reports of acquired lactose intolerance (Oldruitenborgh-Oosterbaan, 2008), none of them in Brazil. Most of the cases reported are most likely to be secondary lactase deficiency (Oldruitenborgh-Oosterbaan, 2008). On the other hand, primary lactose intolerance is a rare congenital condition where there's no production of lactase (beta galactosidase) in the small intestinal brush border (Lester, 2003). There has been a report of two suspected cases of primary lactose intolerance in foals (Roberts, 2008), but no confirmed case was reported in the literature so far. In human medicine, lactose intolerance is not considered a disease, $70 \%$ of the world's population are lactose-intolerant (Ingram and Swallow, 2009).

The determination of the origin of the intolerance is challenging because diagnosis is primarily based on clinical signs and therapy effect (OldruitenborghOosterbaan, 2008), such as the one reported here. However, lactose intolerance diagnosis can be made with oral lactose intolerance test (Martens et al., 1985) with lactose monohydrate $(1 \mathrm{~g} / \mathrm{kg} \mathrm{BW}$ in a $20 \%$ solution) administered via nasogastric tube after four-hour fasting. Plasmatic glucose is monitored from zero hour until 5 hours. Plasmatic glucose levels are expected to increase, reaching its peak around 60 minutes if lactose is absorbed and metabolized properly.

Heyman (2006) also describe another similar lactose tolerance test with administration of lactose at $2 \mathrm{~g} / \mathrm{kg}$ BW (not exceeding $50 \mathrm{~g}$ in a $20 \%$ solution); blood glucose concentration is monitored and if it's maximum increase is equal or lower to $1.4 \mathrm{mmol} / \mathrm{L}$ the diagnosis is of lactose malabsorption. In addition, simple elimination of dietary lactose will cease the diarrhea (Heyman, 2006), although to deprive a foal from milk could be imprudent.

In human medicine genetic, analysis of the lactase gene (LCT-13910 C/T and LCT-22018-G/A) (Oldruitenborgh-Oosterbaan, 2008) and lactose hydrogen breath test are the methods of choice to diagnose lactose intolerance (Beyerlein et al., 2008). Additional exams are helpful to differentiate from other causes of diarrhea and evaluate the severity of bowel impairment. Abdominal ultrasound can be useful to evaluate intestinal wall thickness (OliverEspinosa, 2018), as it was in this report. Blood gas analysis is extremely helpful because foals with severe diarrhea often develop metabolic acidosis (Magdesian, 2005), also observed in the present case. Abdominal radiography can reveal sand and gas accumulation. Blood culture can be useful in case of suspicion of concomitant sepsis. Finally, fecal samples can be used for PCR, ELISA, culture, depending on the agent of suspicion (OliverEspinosa, 2018).

Supplementary treatment is mandatory regardless of the primary cause of diarrhea, since significant fluid derangements are often present, especially in case of severe sepsis, septic shock, and 
hypovolemic shock. A combination of crystalloids and colloids is frequently needed. Also, acidbase balance must be established. Acidosis can be caused by hypoperfusion (hyperlactatemia), being the primary treatment reversing the circulatory disturbances. If acidemia is a result of hyponatremia or relative hyperchloremia, the treatment consists of sodium bicarbonate (Magdesian, 2005). Endotoxin adsorbents include activated charcoal and ditrioctahedral smectite. Kaolin/pectin compounds and bismuth subsalicylate might be used as gastrointestinal protectants (Magdesian, 2005); the last compound was part of therapy instituted in this case, resulting in transient improvement of faeces aspect.

Therapy with probiotics lacks objective research in equine medicine and its mechanism of action is still unknown (Weese, 2002), therefore, it is a controversial treatment. However, probiotics are widely used in practice, commercially available ones are non-spore-forming lactic acid bacteria, as lactobacilli, bifidobacteria, and enterococci (Weese, 2002). Specific lactose intolerance treatment is administration of lactase enzyme $(6000$ Food Chemical Codex units/50-kg foal), P.O., every 3 to $8 \mathrm{~h}$ (Magdesian, 2005; Orsini and Divers, 2014); in the present report, the dosage was $400 \mathrm{mg} / 50 \mathrm{~kg}$ $(8 \mathrm{mg} / \mathrm{kg}$ ) of compounded lactase enzyme every 4 hours, reaching fecal normality in about 8 hours after the first dose. Consecutively, the dose was diminished to twice daily without diarrhea relapse.

\section{Conclusion}

Lactose intolerance usually is secondary to pathogen injury in the brush border epithelium of the villous enterocyte, where lactase is produced. As in this report, most secondary lactose intolerance cases are diagnosed based on clinical signs and response to therapy with lactase enzyme. Here we describe the first case report of secondary lactose intolerance in Brazil and emphasize lactose intolerance as a relevant differential diagnosis of foal diarrhea, especially in animals that fail to respond to therapy but present mild diarrhea without other relevant clinical alterations.

\section{References}

Beyerlein L, Pohl D, Delco F, Stutz B, Fried M, Tutuian R. Correlation between symptoms developed af-ter the oral ingestion of $50 \mathrm{~g}$ lactose and results of hydrogen breath testing for lactose in-tolerance. Aliment Pharmacol Ther. 2008;27(8):659-65.

Cole DJ, Cohen ND, Snowden K, Smith R. Prevalence of and risk factors for fecal shedding of Cryp-tosporidium parvum oocysts in horses. J Am Vet Med Assoc. 1998;213(9):1296-302.

Constable P, Hinchcliff KW, Donne S, Gruenberg W. Veterinary Medicine. 11th ed. St Louis: Elsevier; 2017. p. 175-435.

Davis E, Rush BR, Cox J, DeBey B, Kapil S. Neonatal enterocolitis associated with coronavirus in-fection in a foal: a case report. J Vet Diagn Invest. 2000;12(2):153-6.

Desselberger U. Rotaviruses. Virus Res. 2014;190:75-96.

Diab SS, Songer G, Uzal FA. Clostridium difficile infection in horses: a review. Vet Microbiol. 2013;167(1-2):42-9.

Frederick J, Giguère S, Sanchez LC. Infectious agents detected in the feces of diarrheic foals: a retrospective study of 233 cases (2003-2008). J Vet Intern Med. 2009;23(6):1254-60.

Gustafsson A, Båverud V, Gunnarsson A, Pringle J, Franklin A. Study of faecal shedding of Clostridium difficile in horses treated with penicillin. Equine Vet J. 2004;36(2):180-2.

Guy JS, Breslin JJ, Breuhaus B, Vivrette S, Smith LG. Characterization of a coronavirus isolated from a diarrheic foal. J Clin Microbiol. 2000;38(12):4523-6.

Heyman MB. Lactose intolerance in infants, children, and adoles-cents. Pediatrics. 2006;118(3):1279-86.

Ingram CJE, Swallow DM. Lactose malabsorption. In: McSweeney PLH, Fox PF (Eds.). Advanced dairy chemistry. Volume 3: Lactose, Water, Salts and Minor Constituents. New York: Springer; 2009. p. 203-29. 
Lester, GD. Foal diarrhea. In: Robinson NE (Ed.). Current Therapy in Equine Medicine. 5th ed. Philadelphia: Saunders; 2003. p. 677-80.

Lomer MC, Parkes GC, Sanderson JD. Review article: lactose intolerance in clinical practice-myths and realities. Aliment Pharmacol Ther. 2008;27(2):93-103.

Magdesian KG. Neonatal foal diarrhea. Vet Clin North Am Equine Pract. 2005;21(2):295-312.

Mallicote M, House AM, Sanchez LC. A review of foal diarrhea from birth to weaning. Equine Vet Educ. 2012; 24(4):206-14.

Martens RJ, Malone PS, Brust DM. Oral lactose tolerance test in foals: technique and normal val-ues. Am J Vet Res. 1985;46(10):2163-5.

McGovern K. Diarrhea in the foal. Livestock. 2014;19(2): 128-33.

Myers LL, Shoop DS, Byars TD. Diarrhea associated with enterotoxigenic Bacteroides fragilis in foals. Am J Vet Res. 1987;48(11):1565-7.

Oldruitenborgh-Oosterbaan MMS. Lactose intolerance in foals. Equine Vet Educ. 2008; 20(5):252-5.
Oliver-Espinosa 0. Foal Diarrhea: Established and Postulated Causes, Prevention, Diag-nostics, and Treatments. Vet Clin North Am Equine Pract. 2018; 34(1):55-68.

Orsini, JA, Divers TJ. Equine Emergencies E-Book: Treatment and Procedures. St Louis: Elsevier Health Sciences; 2012. p 225-8.

Reuss SM, Chaffin MK, Cohen ND. Extrapulmonary disorders associated with Rhodococcus equi infection in foals: 150 cases (1987-2007). J Am Vet Med Assoc. 2009;235(7):855-63.

Roberts VLH, Knottenbelt DC, Williams A, McKane SA. Suspected primary lactose intolerance in neonatal foals. Equine Vet Educ. 2008;20(5):249-51.

Slovis NM, Elam J, Estrada M, Leutenegger CM. Infectious agents associated with diarrhoea in neo-natal foals in central Kentucky: a comprehensive molecular study. Equine Vet J. 2014;46(3):311-6.

Uniacke-Lowe T, Huppertz T, Fox PF. Equine milk proteins: chemistry, structure and nutritional significance. Int Dairy J. 2010;20(9):609-29.

Weese JS. Probiotics, prebiotics, and synbiotics. J Equine Vet Sci. 2002;22(8):357-60. 